ІНСТРУМЕНТИ МАКРОПРУДЕНЦІЙНОЇ ПОЛІТИКИ ТА ÏХ ВИКОРИСТАННЯ В УКРАЇНІ

\title{
MACROPRODUCTION POLICY INSTRUMENTS AND THEIR USE IN UKRAINE
}

УДК 336.71

https://doi.org/10.32843/infrastruct39-53

\section{Антонюк О.І.}

аспірантка кафедри банківської справи

Одеський національний економічний університет

Antnonyuk Olena

Odessa National Economic University

\begin{abstract}
Досліджено інструменти макропруденційної політики та їх використання в Україні. Емпіричні результати діяльності банківських систем свідчать про те, що в державах, де макропруденційна політика спрямована на жорсткість умов кредитування для стримування надмірного зростання кредитів $i$ пом'якшення фрінансових ризиків для економіки, простежується тенденція до більш високого і стійкого зростання. Проведено аналіз визначення та класифрікації інструментів макропруденційної політики, рекомендованих міжнародними фрінансовими організаціями та інститутами. Визначено набір інструментів, використовуваних в Україні, та проаналізовано ступінь застосування й ефрективність кожного з них. За результатами дослідження сформульовано висновки та рекомендовано прискорити впровадження інструментів макропруденційного регулювання, визначених у рамках Базеля III, приділяючи особливу увагу інструментам, що вже $є$ в регулятивному арсеналі НБУ. Ключові слова: фрінансова стабільність, макропруденційна політика, макропруденційні інструменти, системний ризик, регулятивний капітал, стрес-тестування, проциклічність.
\end{abstract}

Исследованы инструменты макропруденциальной политики и их использо- вание в Украине. Эмпирические результаты деятельности банковских систем свидетельствуют о том, что в государствах, где макропруденциальная политика направлена на ужесточение условий кредитования для сдерживания чрезмерного роста кредитов и смягчения фринансовых рисков для экономики, прослеживается тенденция к более высокому и устойчивому росту. Проведен анализ определения и классификации инструментов макропруденциальной политики, рекомендованных международными финансовыми организациями и институтами. Определен набор инструментов, используемых в Украине, и проанализированы степень применения и эфроективность каждого из них. По результатам исследования сфрормулированы выводы, и рекомендовано ускорить внедрение инструментов макропруденциального регулирования, определенных в рамках Базеля III, уделяя особое внимание инструментам, что уже есть в регулятивном арсенале НБУ.

Ключевые слова: фринансовая стабильность, макропруденциальная политика, макропруденциальные инструменты, системный риск, регулятивный капитал, стресс-тестирование, процикличность.

The article investigates macroprudential regulation tools and their use in Ukraine. The macroprudential policy has been in the focus of scientific discussions for several years. The vast majority of debates come down to the fact that one cannot deny its effectiveness in ensuring stability of the financial system and preventing and minimizing systemic risk. The paper finds that the empirical results of banking systems indicate that countries in which macro-prudential policies are aimed at tightening lending conditions have a tendency for higher and more sustainable growth. The impact on economic growth is manifested through the channel of acceptance of systemic risk. Macroprudential policy is a set of deliberate actions to eliminate or limit systemic risks in order to prevent or reduce crises; weakening the pro-cyclicality of the financial system and limiting the financial system's endogenous tendency to accumulate imbalances and ensure its financial stability. The key objective of post-crisis approaches to macroprudential policy is to reduce the risk-weighted excess of volatility of assets. The article identifies that Basel III requirements are a guide for national regulators on the application of macroprudential policy instruments. The author analyzes the definition and classification of the tools recommended by international financial organizations and institutions with respect to their groups and the directions of action. Macroprudential instruments are classified in terms of capital regulation, liquidity and asset management. Because of the analysis, the author's classification of the tools according to the nature and use of the appropriate direction of macroprudential policy is offered. It is proposed to focus on the use of regulatory tools as most effective from a practical point of view in the policy implementation. In addition, the author defines a set of the tools used in Ukraine and analyzes the degree of application and effectiveness of each of them. The research based conclusions and proposals are aimed at facilitating the use of macroprudential policy tools, identified as part of Basel III, with an emphasis on the tools that the NBU regulatory arsenal already has. Key words: financial stability, macroprudential policy, macroprudential instruments, systemic risk, regulatory capital, stress testing, pro-cyclicality.

Постановка проблеми. Фінансова криза, яка набула глобального характеру, посилила увагу до подолання системної нестабільності й зумовила пошук нових підходів до раннього виявлення та обмеження впливу системних ризиків на економіку. Емпіричні результати діяльності банківських систем свідчать про те, що в державах, де макропруденційна політика спрямована на жорсткість умов кредитування для стримування надмірного зростання кредитів і пом'якшення орінансових ризиків для економіки, простежується тенденція до більш високого і стійкого зростання. Водночас фрінансова відкритість призводить до ослаблення цього позитивного ефректу, тому що вона забезпечує більшу можливість для внутрішніх фрінансових установ та нефрінансових агентів економічної діяльності запозичувати за кордоном і ізолювати себе від викликаних політикою змін в умовах внутрішнього фрінансового ринку.

Вплив на економічне зростання виявляється через канал прийняття системного ризику. Фінансовий сектор становить основу кредитного та економічного циклів, надаючи тим самим вплив на результативність грошово-кредитної політики й економічне зростання. Необхідність підтримки фрінансової стабільності актуалізує питання уточнення її змісту, основних завдань і срормування набору макропруденційних інструментів відповідно до рекомендацій Групи двадцяти (G20), Групи тридцяти (G30), Міжнародного валютного фонду (МВФ), Базельського комітету 3 питань банківського нагляду, Європейського 
центрального банку та Європейської ради із системних ризиків [1, с. 54].

Аналіз останніх досліджень і публікацій. Дослідженням щодо фрормування набору макропруденційних інструментів присвячено наукові праці учених С. Науменкової [1], В. Міщенка [2], Л. Жердецької [3], В. Коваленко [4], В. Козюка [5], О. Полікарпової [6] та багатьох інших. Проте, незважаючи на постійну увагу до проблем забезпечення фрінансової стабільності в Україні та вдосконалення банківського нагляду з боку вітчизняних науковців, у реаліях вітчизняної практики макропруденційні інструменти не повною мірою можуть бути використані в нашій країні, оскільки для її фрінансової системи характерна висока уразливість до ризиків.

Постановка завдання. Метою дослідження $€$ узагальнення досвіду використання інструментів макропруденційної політики за кордоном та в Україні.

Виклад основного матеріалу дослідження. Основною відмінністю нових підходів є зміщення акценту з мікро- на макрорівень. Реалізація стратегії макропруденційної політики дає змогу сфрормувати комплексне бачення фрінансової системи, яке здатне забезпечити еорективні підходи до регулювання.

Макропруденційна політика - це комплекс цілеспрямованих дій на усунення чи обмеження системних ризиків, щоб запобігти кризам або зменшити втрати від них; послаблення проциклічності фрінансової системи й обмеження ендогенної схильності фінансової системи до нагромадження дисбалансів та забезпечення її фонансової стабільності.

Мету макропруденційної політики можна поділити на два напрями. По-перше, це перевірка розвитку ризиків, які можуть мати системний характер та, своєю чергою, впливати на фрінансову систему країни; по-друге, зміцнення платоспроможності фонансових інститутів та елементів фрінансової системи переважно за рахунок формування капітальних буферів, що забезпечує їх захист у разі виникнення системного ризику [2, с. 36].

Ключовим завданням післякризових підходів до макропруденційної політики є зменшення надмірної мінливості активів [7], зважених з урахуванням ризику RWA, - це сумарні активи банку, зважені за рівнем кредитного ризику відповідно до формули, яка визначається регулятором (зазвичай центральним банком), тобто вартість активів, розрахована шляхом їх угруповання в кілька класів, які відповідають різним оцінним рівням ризику, і множення вартості активів із кожного класу на коефріцієнт, що відображає рівень ризику.

Зміни у нормативній базі під час розрахунку RWA повинні допомагати відновлювати довіру нефінансових корпорацій шляхом підвищення їх надійності та чутливості до ризику; обмеженого використання внутрішніх моделей оцінки ризиків; доповнення коефіцієнта, зваженого за ризиком капіталу, коефріцієнтом левериджу, тобто співвідношення позикових і власних коштів.

Слід звернути увагу на завдання, які повинні виконуватися у процесі реалізації інструментів макропруденційної політики, а саме:

Підтримання стійкості фрінансової системи по відношенню до різних шоків, яке забезпечується за рахунок створення контрциклічних буферів капіталу.

Стримування зростання системних ризиків за рахунок зниження проциклічного впливу цін на кредитні ресурси і активи.

Моніторинг структурних фракторів уразливості фрінансової системи, які утворюються за рахунок взаємозв'язку фрінансових інституцій, їх схильності до ризиків, а також зростаючої ролі системно значимих банків [8]. При цьому стандарт Базеля III за капіталом та ліквідністю для глобальних системно значимих банків (G-SIB) зазвичай переноситься в правила національних регуляторів.

Слід відзначити, що вимоги стандарту Базеля III $€$ керівництвом для національних регуляторів щодо застосування інструментів макропруденційної політики. При цьому перехідні домовленості стосуються мінімальних вимог та строків виконання. Національні регулятори мають право на прийняття більш жорстких стандартів, аніж базельські мінімуми, та впровадження базельських стандартів до встановлення строків. Основні положення Базеля III були завершені наприкінці 2017 р. Сьогодні діють перехідні домовленості Базеля III до 2027 р. (табл. 1).

У грудні 2019 р. Базельський комітет із банківського нагляду опублікував звіти 27 країн про реалізацію ними базельських стандартів за капіталом і ліквідністю, вимог до системно значимих банків (SIBs), позначивши, що залишаються невирішеними проблеми своєчасного прийняття стандартів (табл. 2).

Таким чином, як уже було зазначено вище, сорормовані для виконання вимог Базельського комітету 3 банківського нагляду та реалізації стратегії макропруденційної політики. У світовій практиці застосовується кілька варіантів переліку та класифікації інструментів макропруденційної політики. При цьому проведені дослідження засвідчили, що більш прийнятною та змістовною для України є класифрікація макропруденційних інструментів Ради 3 фрінансової стабільності, МВФ і Банку міжнародних розрахунків (БМР) [2, с. 36] (табл. 3).

Міжнародні організації визначили набір заходів та інструментів, які можуть бути застосовані для досягнення ефрективності макропруденційної політики, а саме: 
Таблиця 1

Перехідні домовленості Базеля III, 2017-2027 pp.

\begin{tabular}{|c|c|c|}
\hline $\begin{array}{l}\text { Покриття } \\
\text { ризиків }\end{array}$ & Статус перехідного режиму & $\begin{array}{c}\text { Третя фраза } \\
\text { Базеля III }\end{array}$ \\
\hline Капітал & $\begin{array}{l}\text { Усі мінімальні вимоги були повністю поетапно виконані до } 2019 \text { р. щодо } \\
\text { контрциклічних вимог до капіталу, обмеження левериджу, динамічного підходу } \\
\text { до резервування. } \\
\text { Капітальні інструменти, які більше не кваліфрікуються як непрофрільний капітал } \\
\text { першого рівня або другого рівня, були припинені з } 2013 \text { р. Остаточна реалізація } \\
\text { вимог -у } 2021 \text { р. }\end{array}$ & $\begin{array}{l}\text { Початкова } \\
\text { фраза } \\
\text { Початкова } \\
\text { фраза }\end{array}$ \\
\hline $\begin{array}{c}\text { Активи } 3 \\
\text { урахуванням } \\
\text { ризику }\end{array}$ & $\begin{array}{l}\text { Реалізація капітальних вимог до інвестицій у фонди та експозицію до } \\
\text { центральних контрагентів, стандартизований підхід до кредитного ризику } \\
\text { контрагента, переглянуто структуру сек'юритизації та ризик процентних ставок } \\
\text { у банківській книзі та межі великих експозицій, які стали повністю есективними. } \\
\text { Переглянуто стандартизований підхід до кредитного ризику та переглянуто } \\
\text { системи IRB, CVAщодо операційного та ринкового ризиків, які набудуть чинності } \\
\text { у } 2022 \text { р. Показник буде поступово введений у } 2022 \text { р. починаючи з 50\%, і він } \\
\text { збільшуватиметься щороку на п'ять відсоткових пунктів до } 2026 \text { р., остаточний } \\
\text { рівень - 72,5\%, досягнутий у } 2027 \text { р. }\end{array}$ & $\begin{array}{l}\text { Початкова } \\
\text { сраза } \\
\text { Заключна } \\
\text { фраза }\end{array}$ \\
\hline Ліквідність & $\begin{array}{l}\text { Коефріцієнт чистого стабільного фрондування та коефріцієнт покриття ліквідності } \\
\text { повністю реалізовано у } 2018 \text { та } 2019 \text { рр. }\end{array}$ & $\begin{array}{l}\text { Початкова } \\
\text { фраза }\end{array}$ \\
\hline Леверидж & $\begin{array}{l}\text { Початкове введення експозиції набуло чинності у } 2018 \text { р. } \\
\text { Переглянуте визначення експозиції та бусрер G-SIB набудуть повноцінної дії у } \\
2022 \text { р. }\end{array}$ & $\begin{array}{l}\text { Заключна } \\
\text { фраза } \\
\text { Початкова } \\
\text { фаза }\end{array}$ \\
\hline
\end{tabular}

Джерело: складено автором за матеріалами [9]

Таблиця 2

Виконання стандартів Базеля III окремими країнами світу

\begin{tabular}{|c|c|c|c|c|c|}
\hline Країна & $\begin{array}{c}\text { Капітал } \\
\text { заснований } \\
\text { на ризику }\end{array}$ & $\begin{array}{c}\text { Коесріцієнт } \\
\text { покриття } \\
\text { ліквідності } \\
\text { (LCR) }\end{array}$ & $\begin{array}{l}\text { Вимоги до } \\
\text { SIBs }\end{array}$ & $\begin{array}{c}\text { Коефріцієнт } \\
\text { чистого } \\
\text { стабільного } \\
\text { фондування } \\
\text { (NSFR) }\end{array}$ & $\begin{array}{c}\text { Контроль } \\
\text { великих ризиків } \\
\text { (LEX) }\end{array}$ \\
\hline Китай & $\begin{array}{c}\text { в/є, вересень } \\
2013 \\
\end{array}$ & в/є, липень 2017 & $\begin{array}{c}\text { в/є, червень } \\
2016 \\
\end{array}$ & о/п (H2 2022) & о/п (H2 2022) \\
\hline $\begin{array}{l}\text { Європейський } \\
\text { Союз }\end{array}$ & $\begin{array}{c}\text { не в/є, грудень } \\
2014 \\
\end{array}$ & $\begin{array}{c}\text { в 3/ст. в/є, } \\
\text { червень } 2017\end{array}$ & $\begin{array}{c}\text { в/є, червень } \\
2016 \\
\end{array}$ & о/п (H2 2020) & о/п (H2 2020) \\
\hline Індія & в/є, червень 2015 & $\begin{array}{c}\text { в 3/ст. в/є, } \\
\text { червень } 2015\end{array}$ & - & о/п (H1 2020) & о/п (H1 2020) \\
\hline Японія & $\begin{array}{c}\text { в/є, жовтень } \\
\text { 2012/грудень } \\
2016 \\
\end{array}$ & в/є, грудень 2016 & $\begin{array}{c}\text { в/є, червень } \\
2016\end{array}$ & о/п (H2 2020) & о/п (H2 2020) \\
\hline Саудівська Аварія & $\begin{array}{l}\text { в/€, вересень } \\
2015\end{array}$ & $\begin{array}{c}\text { в 3/ст. в/є, } \\
\text { вересень } 2015\end{array}$ & - & $\begin{array}{c}\text { в/€, вересень } \\
2018\end{array}$ & $\begin{array}{l}\text { в/є, вересень } \\
2018\end{array}$ \\
\hline Сінгапур & $\begin{array}{c}\text { в/€, березень } \\
2013 \\
\end{array}$ & $\begin{array}{c}\text { в/є, вересень } \\
2018\end{array}$ & - & о/п (H1 2020) & о/п (H1 2020) \\
\hline Південна Афррика & в/є, червень 2015 & в/є, червень 2015 & - & о/п (H1 2021) & о/п (H1 2021) \\
\hline США & $\begin{array}{c}\text { в 3/ст. в/є, } \\
\text { грудень } 2014\end{array}$ & в/є, жовтень 2017 & $\begin{array}{c}\text { в/€, червень } \\
2016\end{array}$ & о/п (H2 2020) & о/п (H2 2020) \\
\hline
\end{tabular}

Примітка: в/є - відповідає; о/п - очікувана публікація документу; з/ст. в/є - у значному ступені відповідає; Н1 - норматив достатності капіталу; Н2 - норматив миттєвої ліквідності.

Джерело: складено автором за матеріалами [10]

Адміністративні заходи, що регулюють темпи зростання кредитування, наприклад установлення верхньої межі для коефіцієнта кредитного забезпечення (співвідношення основної суми кредиту та ринкової чи оціночної вартості застави); визначення верхньої межі для коефіцієнта боргового навантаження (співвідношення суми боргу й сукупного доходу); встановлення лімітів кредитування в іноземній валюті; обмеження на концентрацію кредитного ризику.

Загальні інструменти, які впливають на резерв і капітал: контрциклічний бусрер капіталу, динамічний коефіцієнт фрінансового важеля, динамічні резерви. 
Класифрікація макропруденційних інструментів Радою з фінансової стабільності, МВФ і БМР

\begin{tabular}{|c|l|}
\hline Напрям дії & \multicolumn{1}{|c|}{ Вид } \\
\hline Кредитування & $\begin{array}{c}\text { Нормативи достатності капіталу. } \\
\text { Динамічні норми резервування на можливі втрати від надання кредитів. } \\
\text { Обмеження обсягу і темпів зростання кредитування. } \\
\text { Граничне співвідношення кредиту і вартості застави (Loan-to-Value ratio). } \\
\text { Граничне співвідношення виплат за кредитом і доходу позичальника (Debt } \\
\text { service-to-Income ratio). } \\
\text { Ліміти на маржу }\end{array}$ \\
\hline Системний ризик & $\begin{array}{l}\text { Обмеження щодо невідповідності строків погашення пасивів та активів. } \\
\text { Обмеження на кредитування в іноземній валюті. } \\
\text { Обмеження на відкриті валютні позиції. } \\
\text { Обмеження нецільового фрінансування }\end{array}$ \\
\hline Вразливість фрінансової & Додаткові вимоги до капіталу з урахуванням системної важливості банків. \\
системи & Політика відкритості даних \\
\hline
\end{tabular}

Джерело: складено автором за матеріалами [2, с. 38]

Інструменти, що впливають на певний сектор фрінансового ринку: обмеження вкладень у певні галузі; особливі вимоги, що висуваються до капіталу.

Інструменти, що впливають на ліквідність і валютний ризик: показник чистого стабільного фондування; ліміт на відкриття валютних позицій; інструменти, спрямовані на поповнення високоліквідних активів.

Інструменти, що впливають на структурні ризики: додаткові норми за системну значимість, які можуть висуватися як до капіталу, так і до ліквідності даних інститутів; заходи, що забезпечують контроль взаємозв'язків у межах фондування і на ринках похідних фрінансових інструментів.

Інструменти, які мають пряме обмеження для споживачів фрінансових послуг: інструменти, що обмежують зовнішній борг нефінансових корпорацій; податок на фрізичних осіб в угодах із нерухомістю.

C. Науменкова та В. Міщенко пропонують використання макропруденційних інструментів на основі застосування змінного й постійного підходів, що зумовлює їх поділ на інструменти зі змінними та фріксованими характеристиками.

Макропруденційні інструменти зі змінними характеристиками - це інструменти, коригування яких здійснюється (автоматично чи органом нагляду) відповідно до значень макропруденційних індикаторів, котрі коливаються впродовж економічного циклу. Цей підхід застосовується, наприклад, під час використання контрциклічного буфрера капіталу або динамічного фрормування резервів. Макропруденційні інструменти зі змінними параметрами дають змогу обмежити проциклічні тенденції та ланцюгові ризики, що зростають протягом економічного циклу [1, с. 60].

Макропруденційні інструменти 3 фріксованими характеристиками - це інструменти, значення яких не змінюються залежно від стадій економічного циклу (наприклад, коефріцієнт левериджу, вагові коефіцієнти ризику, стандарти ліцензування чи корпоративного управління) [1, с. 61].

Виходячи з представлених класифікацій інструментів макропруденційної політики, можна зробити висновок, що їх застосування спрямоване у цілому на досягнення однієї узагальненої мети - забезпечення фрінансової стабільності в цілях створення стимулів для економічного зростання.

В Україні інструменти макрпруденційної політики застосовуються Національним банком України в межах розробленої у 2018 р. «Стратегії макропруденційної політики» та визначених у проміжних цілях макропруденційної політики (табл. 4).

В. Козюк відзначив, що застосування макропруденційних інструментів передбачає, що одні з них діють на постійній основі, а окремі з них - залежно від розгортання фрінансового циклу [5, с. 191]. Дослідник також оцінив ефективність застосування макропруденційних інструментів залежно від загального та сировинного аспектів. Виокремив передумови для використання макропруденційних інструментів, а саме: характер економіки і рівень фрінансового розвитку країни; кількісні обмеження, які притаманні макропруденційним інструментам, еорективні до часу вступу дії ефректу заміщення; врахування фрактору відносної ефективності макропруденційних інструментів; важливість урахування валютного курсу у підтримці фрінансової стабільності; врахування фактору сировинної залежності країни під час проведення макропруденційної політики; з'ясування питання щодо системної вразливості, яка викликана непрозорою діяльністю олігархічного банкінгу, кредитуванням пов'язаних осіб та офшшорингом.

Слід відзначити, що центральні банки відіграють важливу роль у зменшенні системних ризиків. Ефективне пом'якшення системного ризику вимагає від фрінансової системи, зокрема від центральних банків, добре розвинутої аналітичної методології моніторингу системного ризику. Механізм моніторингу систем раннього попередження криз 
Інструменти макропруденційної політики в Україні

\begin{tabular}{|c|c|}
\hline Інструменти & Характеристика \\
\hline \multicolumn{2}{|r|}{ Інструменти капіталу } \\
\hline $\begin{array}{l}\text { Бусрер ко } \\
\text { (capital c }\end{array}$ & $\begin{array}{l}\text { Формується в нестресовий період для покриття збитків та недопущення } \\
\text { порушення мінімальних вимог до достатності капіталу в майбутньому. Активація } \\
\text { передбачена у } 2020 \text { р., буфер становитиме 0,625\% з поетапним збільшенням до } \\
2,5 \% \text { до початку } 2023 \text { р. }\end{array}$ \\
\hline $\begin{aligned} \text { Ko } \\
\text { (coun }\end{aligned}$ & $\begin{array}{l}\text { ться у період кредитної експансії, знижується або деактивується в періоди } \\
\text { чного спаду. Знижує проциклічність фрінансової системи. Залежно від фрази } \\
\text { чного циклу може коливатися від 0\% до } 2.5 \% \text {. }\end{array}$ \\
\hline $\begin{array}{l}\text { Бурер сист } \\
\text { (buffer fo } \\
\text { impor }\end{array}$ & $\begin{array}{l}\text { Посилює стійкість системно важливих установ. Установлюється залежно від } \\
\text { категорії системної важливості банку від 1\% до 2\%. }\end{array}$ \\
\hline $\begin{array}{r}\text { Бyqpep ch } \\
\text { (systeI }\end{array}$ & $\begin{array}{l}\text { Зниження вразливості до довготермінових структурних (нециклічних) системних } \\
\text { ризиків. Цей буфер сьогодні не передбачений нормами НБУ. } \\
\end{array}$ \\
\hline $\begin{array}{r}\text { Koeqpiц } \\
\text { (lev }\end{array}$ & $\begin{array}{l}\text { Мінімальне відношення капіталу першого рівня до всіх активів (балансових } \\
\text { та позабалансових), незважених на ризик. Планується запровадження у } \\
\text { майбутньому, мінімальний рівень не визначено. }\end{array}$ \\
\hline $\begin{array}{r}\text { Дод } \\
\text { ок } \\
\end{array}$ & $\begin{array}{l}\text { 3більшення обсягу капіталу на покриття л } \\
\text { кредитів. Потенційно може застосовуватис }\end{array}$ \\
\hline \multicolumn{2}{|r|}{ Інструменти ліквідності } \\
\hline $\begin{array}{r}\text { КоесріL } \\
\text { ліквідністю } \\
\text { ra }\end{array}$ & $\begin{array}{l}\text { Визначає, скільки високоякісних ліквідних активів має утримувати банк, щоб } \\
\text { покрити чисті відтоки коштів протягом } 30 \text { днів у кризовий період. Запроваджено у } \\
\text { грудні } 2018 \text { р. }\end{array}$ \\
\hline $\begin{array}{r}\text { Koеqрi } \\
\text { стабільного } \\
\text { stable fun }\end{array}$ & $\begin{array}{l}\text { Визначає мінімальну частку стабільного (довгострокового) фондування } \\
\text { залежно від ліквідності та залишкової строковості активів. Спонукає банки } \\
\text { переорієнтовуватися на довгострокові джерела фрінансування. Запровадження } \\
\text { планується у } 2020 \text { р. }\end{array}$ \\
\hline \multicolumn{2}{|r|}{ Інші інструменти } \\
\hline $\begin{array}{l}\text { Граничне співвідношення } \\
\text { розміру кредиту та вартості } \\
\text { забезпечення (loan-to-value } \\
\text { ratio, LTV) }\end{array}$ & $\begin{array}{l}\text { Обмежує максимальний розмір кредиту домогосподарствам залежно від вартості } \\
\text { забезпечення. Найчастіше застосовується до іпотечних кредитів, запобігає } \\
\text { виникненню бульбашок на ринку нерухомості. Використання як жорсткого } \\
\text { обмеження у найближчі роки малоймовірно, проте можливе оприлюднення } \\
\text { рекомендацій банкам. }\end{array}$ \\
\hline $\begin{array}{c}\text { Граничне співвідношення } \\
\text { суми обслуговування боргу та } \\
\text { доходу позичальника (debt- } \\
\text { service-toincome ratio, DSTI) } \\
\text { або загальної суми кредиту } \\
\text { та доходу (debt-toincome ratio, } \\
\text { DTI). } \\
\end{array}$ & $\begin{array}{l}\text { Обмежують максимальну суму кредиту, який може отримати домогосподарство } \\
\text { залежно від рівня його доходів. Запобігають надмірному зростанню кредитування } \\
\text { та заборгованості домогосподарств. Використання як жорсткого обмеження у } \\
\text { найближчі роки малоймовірно, проте можливе оприлюднення рекомендацій } \\
\text { банкам. }\end{array}$ \\
\hline $\begin{array}{l}\text { Підвиш } \\
\text { розкрит }\end{array}$ & $\begin{array}{l}\text { форормованість громадськості про діяльність фрінустанов, } \\
\text { ансової системи. }\end{array}$ \\
\hline
\end{tabular}

Джерело: складено автором за матеріалами [4, с. 328]

(переважно макроекономічних, на базі випереджальних індикаторів) і оцінок банківського сектору за різними економетричними моделями, а також їх використання залежить від умов функціонування фрінансового ринку та фраз економічного циклу [6, с. 331]. Тому за доцільне є оцінювання ефективності використання макропруденційних інструментів із позицій розміру витрат на застосування таких інструментів, а також із побічними ефектами та наслідками (рис. 1).

У 2019 р. Національним банком України було проведено стрес-тестування 29 банків, на які припадає загалом понад 90\% активів банківської системи. Було зроблено середньозважені оцінки нормативу достатності основного капіталу банків за результатами стрес-тестування [12]. У середньому достатність основного капіталу за базового сценарію для всіх банків, що проходили стрестестування, зростає у прогнозному періоді майже на 10 в. п., до 19,8\%. Більшість проаналізованих банків залишається достатньо прибутковою, а рівень їхнього капіталу зростає. Попри це, 11 банків потребували збільшення капіталу для досягнення мінімально необхідного рівня достатності за базовим сценарієм. За несприятливого сценарію капітал 18 банків опускається нижче граничного рівня, який для нормативу достатності основного капіталу становив усього $3,5 \%$, регулятивного $5 \%$. Загальний кумулятивний вплив гіпотетичної кризи на основний капітал сягає майже 7,5 в. п. нормативу достатності - цей показник знижується до 2,4\% у трирічному прогнозному періоді. 


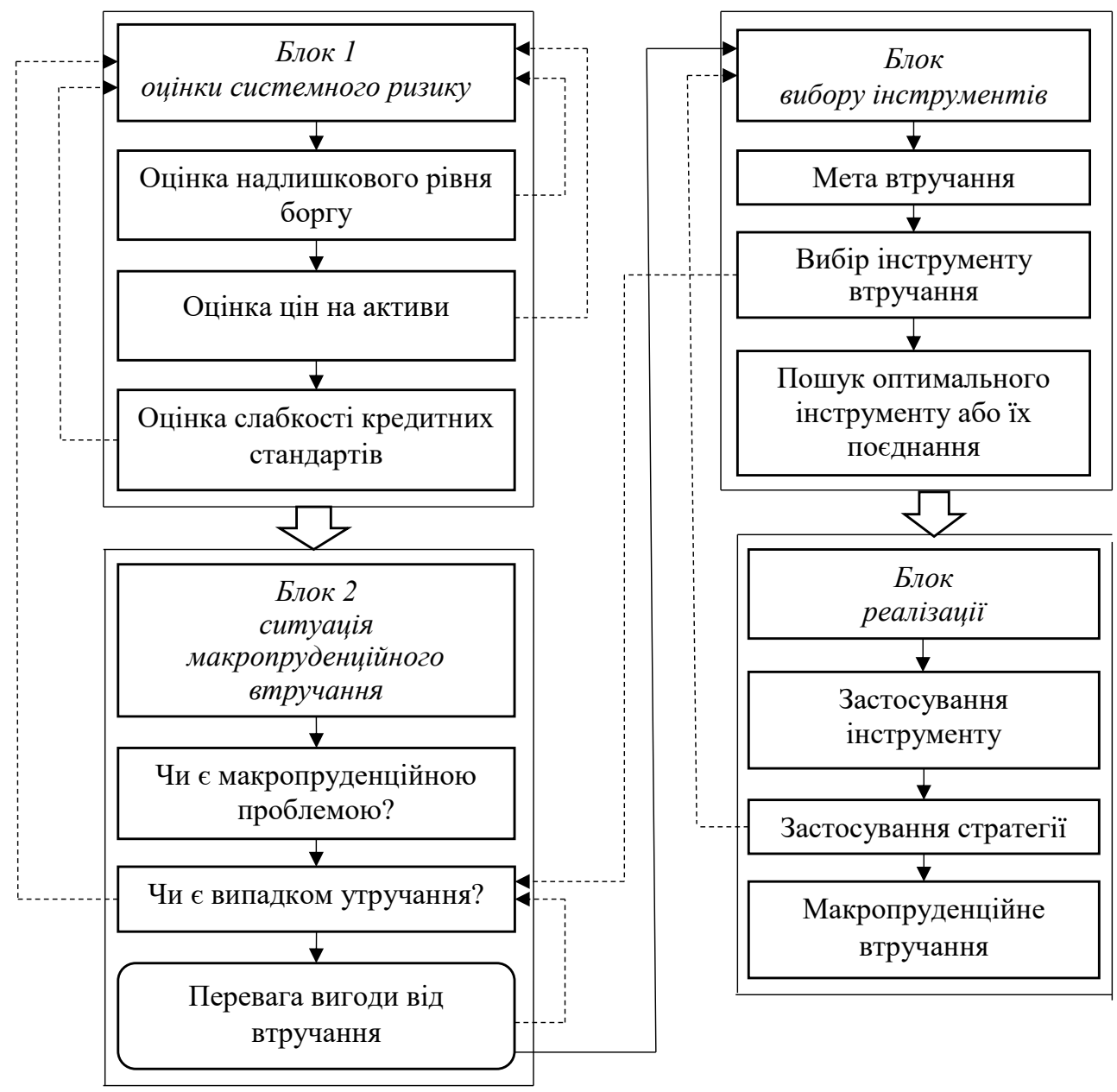

Рис. 1. Послідовність дій у прийнятті рішень щодо макропруденційного втручання

Джерело: складено автором за матеріалами [11]

Найгірші результати як за базового, так і за несприятливого сценарію продемонстрували російські банки. Це пов'язано із їхнім поступовим згортанням, відсутністю якісних активів та достатніх доходів від основної діяльності. Погіршилися результати стрес-тестування державних АТ «Ощадбанк» та AT «Укрексімбанк». Перш за все, через амортизацію застави за старими непрацюючими кредитами. Дев'ять банків удруге успішно проходять стрес-тестування. Більшість із них - іноземні, а також державні ПАТ КБ «Приватбанк» та АТ «Укргазбанк». Серед банків, що у 2018 р. потребували капіталу, у 2019 не виявлено його нестачі для ПАТ «ПУМБ» та ПАТ «Альфа-Банк». Висновки з проведеного дослідження. У вітчизняній практиці застосовуються переважно банківські пруденційні інструменти, що обмежує сфреру комплексного моніторингу за джерелами й каналами поширення системних ризиків. Макро стрес-тести та аналіз банківських балансів залишаються основними інструментами моніторингу таких ризиків у банківському секторі України, котрий характеризується високою системною уразливістю. Для повнішого врахування циклічних тенденцій у економіці доцільно розширити використання макропруденційних інструментів зі змінними параметрами.

У 2019 р. прийнято низку конструктивних рішень для згладжування дисбалансів у фрінансовій системі, зокрема: змінено архітектуру регулювання небанківського фрінансового сектору, впроваджено нові механізми захисту прав та інтересів споживачів фінансових послуг; удосконалено підходи до врегулювання заборгованості за непрацюючими активами; удосконалено національне законодавство у сфері фрінансового моніторингу; продовжено валютну лібералізацію; змінено підходи до оцінки кредитного ризику за цінними паперами; пом'якшено графрік збільшення мінімального розміру капіталу; спрощено умови роботи банків із малим бізнесом; спрощено порядок видачі небанківськими установами ліцензії на переказ коштів; змінено вимоги до обов'язкових резервів банків. Уважається, що зазначені заходи будуть сприяти подальшій стабілізації на фрінансовому ринку та досягненню проміжних цілей макропруденційної політики. 


\section{БІБЛІОГРАФИЧНИЙ СПИСОК:}

1. Науменкова С., Міщенко В. Макропруденційні інструменти в механізмі забезпечення фрінансової стабільності. Фінанси України. 2015. № 10. С. 53-76.

2. Міщенко В.І., Бауман О.С. Система інструментів макропруденційного регулювання та їх використання в Україні. Наукові праці НДФІ. 2016. № 4(77). С. 34-45.

3. Жердецька Л.В. Макропруденційна політика: світовий досвід та українська практика. Вісник соціально-економічних досліджень. 2016. Вип. 1(60). С. 239-246.

4. Коваленко В.В., Радова Н.В. Моніторинг фрінансової стабільності банківської системи України. Східна Європа: економіка, бізнес та управління. 2019. Вип. 2(19). С. 321-330.

5. Козюк В. Поширення макропруденційного регулювання та орієнтири макропруденційної політики НБУ. Журнал Європейської економіки. 2018. Т. 17. № 2(65). C. 185-207.

6. Полікарпова О. Макропруденційна політика: мета, інструменти та можливості для України. Актуальніпроблеми економіки. 2016. № 5(179). С. 327-335.

7. Williamson S.D. Low real interest rates. collatera misrepresentation, and monetary policy. American Economic Journal: Macroeconomics. 2018. № 10(4), P. 202-233. DOI : 10.1257/mac.20150035.

8. Aikman D., Andrew G., Haldane Benjamin D. Nelson. Curbing the credit cycle. The Economic Journal. 2013. № 125(585). P. 1072-1109. DOI : 10.1111/ ecoj.12113.

9. Implementation of Basel III - Executive Summary Transitional arrangements and the RCAP process. Financial Stability Institute. URL : https://www.bis.org/ fsi/fsisummaries/imp_basel3.pdf (дата звернення: 19.01.2020).

10. Seventeenth progress report on adoption of the Basel regulatory framework. Basel Committee on Banking Supervision. October, 2019. URL : https:// www.bis.org/bcbs/publ/d478.pdf (дата звернення: 19.01.2020).

11. Стратегія макропруденційної політики. 2018 р. URL : https://bank.gov.ua/files/zgNZIvZgKdapdeO (дата звернення: 12.01.2020).

12. Стрес-тестування банків у 2019 році / Національний банк України. URL : https://bank.gov.ua/files/ oALUrXBwHLWrwmD (дата звернення: 19.01.2020).

\section{REFERENCES:}

1. Naumenkova S., Mishchenko V. (2015). Makroprudentsiyni instrumenty $v$ mekhanizmi zabezpechennya finansovoyi stabil'nosti [Macroprudential tools in the mechanism of ensuring financial stability]. Finansy Ukrayiny - Finance of Ukraine, no. 10, pp. 53-76.
2. Mishchenko V.I., Bauman O.S. (2016) Systema instrumentiv makroprudentsinoho rehulyuvannya ta yikh vykorystannya v Ukrayini [System of macroprudential regulation tools and their use in Ukraine]. Naukovi pratsi NDFI - Scientific research works of the Institute, no. 4 (77), pp. 34-45.

3. Zherdetska L.V. (2016) Makroprudentsiyna polityka: svitovyy dosvid ta ukrayins'ka praktyka [Macroprudential policy: world experience and Ukrainian practice]. Visnyk sotsial'no-ekonomichnykh doslidzhen' - Bulletin of socio-economic research, vol. 1 (60), pp. 239-246.

4. Kovalenko V.V., Radova N.V. (2019) Monitorynh finansovoyi stabil'nosti bankivs'koyi systemy Ukrayiny [Monitoring of financial stability of the banking system of Ukraine]. Skhidna Yevropa: ekonomika, biznes ta upravlinnya - Eastern Europe: Economy, Business and Management, no. 2 (19), pp. 321-330.

5. Kozyuk V. (2018) Poshyrennya makroprudentsiynoho rehulyuvannya ta oriyentyry makroprudentsiynoyi polityky NBU [Dissemination of macroprudential regulation and benchmarks of NBU macroprudential policy]. Zhurnal Yevropeys'koyi ekonomiky - Journal of the European Economy, vol. 17, no. 2 (65), pp. 185-207.

6. Polikarpova O. Makroprudentsiyna polityka: meta, instrumenty ta mozhlyvosti dlya Ukrayiny [Macroprudential policy: goals, tools and opportunities for Ukraine]. Current problems of the economy - Current problems of the economy, vol. 5, no. 179, pp. 327-335.

7. Williamson, Stephen D. (2018) Low real interest rates. collateral misrepresentation, and monetary policy. American Economic Journal: Macroeconomics, no. 10(4), pp. 202-33. DOI: 10.1257/mac.20150035.

8. Aikman D., Andrew G., \& Haldane Benjamin D. Nelson. (2013) Curbing the credit cycle. The Economic Journal, no. 125(585), pp. 1072-1109. DOI:10.1111/ ecoj.12113.

9. Implementation of Basel III - Executive Summary Transitional arrangements and the RCAP process. Financial Stability Institute. Available at: https://www.bis.org/fsi/fsisummaries/imp_basel3.pdf. (accessed 19 January 2020).

10. Seventeenth progress report on adoption of the Basel regulatory framework. Basel Committee on Banking Supervision. (October, 2019). Available at: https://www.bis.org/bcbs/publ/d478.pdf. (accessed 19 January 2020).

11. Stratehiya makroprudentsiynoyi polityky [Macroprudential policy strategy]. 2018. Available at: https://bank.gov.ua/files/zgNZIvZgKdapdeO. (accessed 12 January 2020).

12. Stres-testuvannya bankiv u 2019 rotsi. Natsional'nyy bank Ukrayiny [Banks' stress testing in 2019. National Bank of Ukraine]. Available at: https://bank.gov.ua/files/oALUrXBwHLWrwmD. (accessed 19 January 2020). 